\title{
Happiness Decreases during Early Adolescence-A Study on 12- and 15-Year-Old Finnish Students
}

\author{
Lotta Uusitalo-Malmivaara \\ University of Helsinki, Helsinki, Finland \\ Email: lotta.uusitalo-malmivaara@helsinki.fi
}

Received 31 January 2014; revised 25 February 2014; accepted 18 March 2014

Copyright (C) 2014 by author and Scientific Research Publishing Inc.

This work is licensed under the Creative Commons Attribution International License (CC BY). http://creativecommons.org/licenses/by/4.0/

(c) (i) Open Access

\begin{abstract}
Global and school-related happiness were measured in 339 Finnish ninth graders, about $86 \%$ of whom had participated in a study on the happiness of sixth graders three years earlier. Students filled out two questionnaires, the Subjective Happiness Scale (Lyubomirsky \& Lepper, 1999) and the School Children's Happiness Inventory (Ivens, 2007). In addition, they chose items that they perceived would increase their happiness from a given list. Both global and school-related happiness had decreased since the sixth grade. Especially in girls, the decline was dramatic. The decrease in happiness was mostly attributed to peer problems and, to a lesser extent, stress at school. The factor most desired to increase happiness was more success at school followed by the desire for more money, more free time and a girlfriend or boyfriend. Girls with a high grade-point average were happier than other girls, globally and at school. Among boys, no such differences appeared.
\end{abstract}

\section{Keywords}

Happiness, School-Related Happiness, Happiness-Increasing Factors, Ninth Graders, Adolescents, GPA, Secondary School

\section{Introduction}

During the past ten years, research on children's and adolescents' happiness has grown (for a review, see Proctor, Linley, \& Maltby, 2009). Studies from all over the world show high degrees of happiness and life satisfaction in most children and adolescents (Gilman \& Huebner, 1997; Holder, 2012: pp. 67-68; Huebner \& McCullough, 2000; Uusitalo-Malmivaara, 2012; Uusitalo-Malmivaara et al., 2012). Regardless of culture or wealth, the large 
majority of children rate themselves as being at least moderately happy (Holder, Coleman, \& Singh, 2012; Park \& Huebner, 2005). In this study, happiness is defined as a synonym for subjective well-being (Diener, 1984), a broad concept of people's physical and mental health and emotional well-being (Lyubomirsky, 2007: p. 317; Lyubomirsky \& Lepper, 1999; Lyubomirsky, Sheldon, \& Schkade, 2005). Subjective well-being can be further divided into three components: positive affect, negative affect and life satisfaction (Diener, 1984), the last being an overall cognitive appraisal of how good one's life is, a complementary component to the affect components.

Studies focusing on the development of happiness during the teenage years are few (Holder, 2012: p. 40). Unlike the scarcity of studies on changes in happiness, an increase in depression during adolescence, starting from the age of about 15, is well documented (Brooks-Gunn \& Petersen, 1991; Hankin et al., 1998; Nolen-Hoeksema \& Girgus, 1994; Petersen, Compas, Brooks-Gunn, Stemmler, \& Grant, 1993). Also, global life satisfaction has been shown to decline with the onset and progression of adolescence (Bisegger et al., 2005; Goldbeck, Schmitz, Besier, Herschbach, \& Henrich, 2007; Park, 2005; Suldo \& Huebner, 2004). Yet happiness, when it is defined as equivalent to subjective well-being or SWB (Diener, 1984), is not the complete flip side of depression (Cheng \& Furnham, 2003; Keyes, 2005). Nor is it a synonym for life satisfaction which only measures the cognitive aspect of subjective well-being, leaving the affective components unexplored (Diener, 1984). Furthermore, lifespan studies of subjective well-being have thus far not included children or adolescents (Baird, Lucas, \& Donnellan, 2010). Thus, we found it justifiable to ask what happens to happiness during the years of transition from childhood to adolescence.

Our informants were 339 ninth graders, about 86\% of whom had participated in our study on global and school-related happiness involving more than 700 sixth graders three years before (Uusitalo-Malmivaara, 2012). In Finland, compulsory education starts at the age of seven, and the basic educational curriculum lasts nine years. These nine years are divided into two parts: primary school (grades-6) and lower secondary school (grades 7-9). After completing compulsory education, most students enter general upper academic secondary school or vocational education (Finnish National Board, 2012). The participants in the current study were on the threshold of this decisive transition. They were about to finish compulsory school and apply for upper secondary education.

First, we review the literature most pertinent to our study. What are the correlates of youth happiness globally and in the context of school, and what are the challenges that young people face when they enter adolescence?

\section{Correlates of Youth Happiness}

As with adults, the correlates of youth happiness and life satisfaction mostly lie in personality traits and temperament (Diener, 1996; Holder \& Klassen, 2010; Huebner, 1991; Lyubomirsky, Sheldon, \& Schkade, 2005). High extraversion and low neuroticism predict happiness in adults and adolescents (Furnham \& Cheng, 2000; McKnight, Huebner, \& Suldo, 2002), whereas high sociability and low emotionality are predictors of children’s happiness (Holder \& Klassen, 2010). Zest, gratitude, hope, and love are the character strengths most often connected with high life satisfaction and happiness, both in adults and youths (Park \& Peterson, 2006, 2008; Peterson, Ruch, Beermann, Park, \& Seligman, 2007).

Social relationships and popularity among peers (Chaplin, 2009; Holder \& Coleman, 2009; Uusitalo-Malmivaara \& Lehto, 2013) strongly predict happiness. Friendship experiences promote individuals’ feelings of uniqueness and provide a context in which basic needs are satisfied. Furthermore, friendship quality predicts happiness above and beyond the influence of personality (Demir \& Özdemir, 2010; Demir, Şimşek, \& Procsal, 2012; Demir \& Weitekamp, 2007).

Freely-chosen leisure activities and especially physical exercise (Holder, Coleman, \& Sehn, 2009; Sacker \& Cable, 2006) are important predictors of youth happiness. Sport promotes health, increases self-confidence and contributes to a satisfying life (Csikszentmihalyi \& Hunter, 2003). Additionally, physical activities also provide a means for youth to get together. Thus, social affiliation may enhance the positive effects of physical exercise (Fredricks et al., 2002; Holder et al., 2009).

Physical appearance correlates with happiness only weakly (Diener, 1995; Holder \& Coleman, 2008). However, good looks are correlated with popularity or imagined popularity (Feingold, 1992) and induce strong inferences about extraversion and social competence probably facilitating the making of friends (Eagly, Ashmore, Makhijani, \& Longo, 1991). Also, self-rated attractiveness is related to happiness (Neto, 2001), probably via self-esteem, which strongly predicts life satisfaction and happiness (Huebner, Gilman, \& Laughlin, 1999).

Money and happiness do not go hand-in-hand, although a weak correlation exists between income and happi- 
ness at the national level (Diener \& Biswas-Diener, 2002). After one’s basic needs have been met, extra money usually brings no greater happiness (Diener, Sandvik, Seidlitz, \& Diener, 1993; Veenhoven \& Ehrhardt, 1995). Focusing on money may even result in less happiness. In a study by Nickerson and colleagues (Nickerson, Schwarz, Diener, \& Kahneman, 2003), it was shown that those who set a high income as their primary career goal ended up being less happy than their peers twenty years later. Money can also be a means of achieving social goals and practicing charity, activities that are closely associated with happiness (Lyubomirsky et al., 2005). Indeed, spending money on others seems to promote happiness (Dunn, Aknin, \& Norton, 2008).

Happiness in the school context arises from social and academic factors that are intertwined and affect each other. Previous research has shown culture-dependent results of the importance of grades and other formal learning achievements (e.g., Chang, McBride-Chang, Stewart, \& Au, 2003). In a comparison between US and Korean students, a significant correlation between satisfaction in school and global satisfaction was found only among the Korean students (Park \& Huebner, 2005). In a study of Finnish 12-year-olds, better success in school was the most desired of the happiness-increasing factors (Uusitalo-Malmivaara, 2012). Learning difficulties, mental disabilities, or IQ do not seem to be associated with happiness (Brantley, Huebner, \& Nagle, 2002; McCullough \& Huebner, 2003; Suldo, Riley, \& Shaffer, 2006). Special class placement has been shown to predict lowered happiness in one study. Presumably, multiple factors were involved in this result (Uusitalo-Malmivaara et al., 2012). In a study by Gilman and Huebner (2006), students who reported high global life satisfaction also reported more positive school experiences, higher grade-point averages, and more participation in extracurricular activities. Guided by the self-determination theory of Deci and Ryan (1985), Baker and colleagues listed three most significant school practices that are associated with increased school satisfaction: children's meaningful connections to teachers and peers, children's sense of competence as learners, and children's sense of autonomy and self-regulation (Baker, Dilly, Aupperlee, \& Patil, 2003).

\section{Transition from Childhood to Adolescence}

The years from 12 to 15 are characterized by challenges in multiple areas. Physiological and psychological changes, alterations in social behavior, cognitive maturation, greater demands at school and increased independence create stress (developmental tasks, Havighurst, 1966), that need to be dealt with. Changes at puberty affect emotional well-being, and psychological crises often accompany entry into adolescence. The majority of adolescents of both genders successfully negotiate the developmental period without any major psychological or emotional disorder (Petersen et al., 1993; Powers, Hauser, \& Kilner, 1989).

At the time of adolescence, the challenges and burdens that girls and boys face start to differ increasingly. A great deal of research shows higher rates of psychosomatic disorders, emotional disturbances, depression, and anxiety among adolescent girls as compared to boys (e.g., Angold, Costello, Erkali, \& Worthman, 1999; NolenHoeksema, 1994; Rask, Åstedt-Kurki, Paavilainen, \& Laippala, 2003). According to the report of European Commission (2000) and recent national studies (Karvonen, Vikat, \& Rimpelä, 2005; Salmela-Aro, Kiuru, Pietikäinen, \& Jokela, 2008; Terveyden ja hyvinvoinnin laitos, 2012), health-related complaints increase especially among girls during adolescence, and there is a "shift in gender-related health status between childhood and adolescence". Boys are more likely than girls to have health problems up to puberty but the trend is reversed in adolescence (European Commission, 2000: p. 17). The reasons may lie in the girls' physically more drastic puberty changes, greater social demands, controversial role expectations, and more frequent school-related burnout (Angold et al., 1999; Bisegger et al., 2005; Kaltiala-Heino, Marttunen, Rantanen, \& Rimpelä, 2003; SalmelaAro et al., 2008).

Our precise research questions were: 1) How happy are ninth graders globally and in a school context? 2) What would add to their happiness? 3) Have the happiness levels changed from the sixth grade, and if so, what do the students think is the reason for this change? 4) What items did students at different levels of global happiness believe would increase their happiness? 5) Is academic success in terms of grade point average connected with happiness? And finally, 6) are specific future plans connected to global and school-related happiness? Gender differences were studied in connection with every question.

\section{Methods}

\subsection{Participants}

The participants were 339 ninth graders (age range $14-16, M 15.15, S D$ 0.48) in a city of about 83,000 inhabi- 
tants in western Finland. This city was chosen because of its homogeneous population, with only approximately $1 \%$ of the population having an immigrant background. Also, the social-economic backgrounds of inhabitants cover a large spectrum and are assumed to represent the whole of Finland satisfactorily. The city's educational authorities gave permission for the study and forwarded the link on the electronic questionnaire to every lower secondary school in the city. Special education schools and classes were not included. Parents were fully informed about the study, and participants were able to withdraw if they wished. Of all ninth graders in the city, $40.6 \%$ participated.

The students were surveyed in computerized classrooms during a normal class period during two weeks in January 2012. Teachers trained in the task instructed participants in a standardized way. Students completed the questionnaire alone and anonymously within 15 minutes.

\subsection{Instruments and Procedures}

Two questionnaires and two separate questions were used to study adolescents' happiness: The Subjective Happiness Scale (SHS), School Children's Happiness Inventory, (SCHI), a multi-choice question concerning happiness-increasing factors, and a qualitative question concerning reasons for change in global happiness. The measures of happiness included a total of 31 items. Additionally, a questionnaire probing the socio-demographic variables of age, gender, most recent academic GPA, plans for the future, and attendance of the sixth grade in the same city was administered.

The Subjective Happiness Scale is a four-item test aimed at measuring global happiness (Lyubomirsky \& Lepper, 1999). The first item asks respondents to characterize their happiness using absolute ratings. The second item asks for ratings relative to peers. The third item asks respondents to compare their happiness to very happy persons, and the fourth asks them to compare their happiness to very unhappy persons. The response format is a seven-point Likert scale, and a single composite score is computed by averaging responses to the four items, the fourth item being reverse-coded (range 1 - 7). The average scores of the scale range between 4.5 and 5.5. In the present study, the scale's internal consistency was acceptable, Cronbach's $\alpha=0.64$.

School Children's Happiness Inventory (SCHI, Ivens, 2007) is a context-related questionnaire aimed at measuring happiness in children aged 8 - 15. The SCHI offers a simple response format with 15 positive and 15 negative SWB items (e.g., "I felt relaxed", or "I wanted to give up"); see Table 5. Participants are asked to rate their thoughts and feelings during the previous week at school. Each response to each SCHI item is scored from 1 to 4, with four indicating a high level of happiness. Half of the items are reverse-coded to yield a total SWB. The composite score is computed by averaging all the items. We used the shortened 25-item Finnish version (e.g. Uusitalo-Malmivaara et al., 2012), which has proven to have a high and stable internal consistency. In the present study, Cronbach's $\alpha$ was 0.90 . The average scores have ranged between 3.09 - 3.26 on the 30-item and 25-item measures (Ivens, 2007; Uusitalo-Malmivaara, 2012; Uusitalo-Malmivaara et al., 2012).

Happiness-increasing factors were asked by presenting a list of 19 alternative choices (see Table 2) plus an option for items that make people happy. The respondents could choose as many of these options as they wished. The first 12 options were similar to those presented to sixth graders in our previous study (Uusitalo-Malmivaara, 2012). The seven new options were based on the literature concerning youths' happiness and life satisfaction (Huebner, 1991; Gilman \& Huebner, 2003; Holder et al., 2009; Holder \& Coleman, 2008, 2009; Proctor et al., 2009).

Reasons for change in global happiness were asked by a three-part question: "Since the sixth grade, has your global happiness remained the same, decreased, or increased?” After that, the respondents were asked to describe qualitatively the reasons for the stability or change in their happiness.

As background variables, the respondents were asked to report their gender and age. The most recent academic grade point average (GPA) was asked in a self-reported format by presenting a list of GPA ranges. In Finland, numerical grades range from 4 (fail) to 10 (excellent). Traditionally, grade reports are given twice a year, in December and May. The respondents were asked: "What was your latest academic grade point average?" A choice was made from a list of 12 different ranges (4.0 - 4.5; 4.6 - 5.0; ..., 9.6 - 10.0). In the present study, the GPAs had been obtained one month before, in December 2011.

The respondents were asked a single question about their future plans: "What have you planned to do after the ninth grade (after the finishing compulsory school)"? There were five options: upper secondary (academic) school, vocational school, start to work, have a year off, and I don't know yet. 
Where respondents attended sixth grade was determined by a single question. "Did you attend the sixth grade in this city?” The options were yes, no, and I don't know. This question was administered to determine if the respondents had been included in our previous study on sixth graders. In 2009, 95.3\% of all the sixth graders in the same city participated in the study (Uusitalo-Malmivaara, 2012).

\section{Results}

\subsection{Global and School-Related Happiness}

A total of 182 girls and 157 boys completed the questionnaire. The descriptive statistics for happiness divided by gender are shown in Table 1. Ratings of global happiness varied from 1.0 to 7.0, and the SCHI scores ranged from 1.0 to 4.0. There was a difference between girls and boys in school-related happiness. On the Subjective Happiness Scale (the measure for global happiness), $10.9 \%$ of the participants had a mean value of less than four (scale 1-7), indicating an overall unhappy state. In the SCHI, 3.8\% of the participants had a mean value of two or less (scale 1-4), indicating overall unhappiness in the school context. The Pearson's correlation between the global and school-related happiness was $0.59, p<0.001$.

\subsection{Change in Happiness Levels since the Sixth Grade}

Three years earlier, we had asked the same respondents about their global and school-related happiness (Uusitalo-Malmivaara, 2012). Those results were compared with the ones obtained in this study. Both global and school-related happiness had significantly decreased during the three years. In the sixth grade, the mean of both girls' and boys' global happiness was 5.30 and ( $S D=0.88$ and $S D=0.87$, respectively). According to the univariate analysis of variance, there was a main effect of time, $F(1)=23.28, p<0.001, \eta 2=0.02$. No main effect of gender, $p>0.05$, or interaction effect between time and gender, $p>0.05$, were detected (see Figure 1 ).

Table 1. Descriptive statistics for global and school-related happiness measures.

\begin{tabular}{|c|c|c|c|c|c|c|c|c|c|}
\hline & \multicolumn{3}{|c|}{ Girls } & \multicolumn{3}{|c|}{ Boys } & \multicolumn{3}{|c|}{ All } \\
\hline & $n$ & $M$ & $S D$ & $n$ & $M$ & $S D$ & $n$ & $M$ & $S D$ \\
\hline Global happiness & 182 & 5.00 & 1.05 & 157 & 5.05 & 0.98 & 339 & 5.01 & 1.01 \\
\hline SCHI & 182 & 3.04 & 0.54 & 157 & 3.16 & 0.51 & 339 & 3.09 & 0.53 \\
\hline
\end{tabular}

Note: Global happiness, scale 1-7; SCHI = School Children’s Happiness Inventory, scale 1-4.

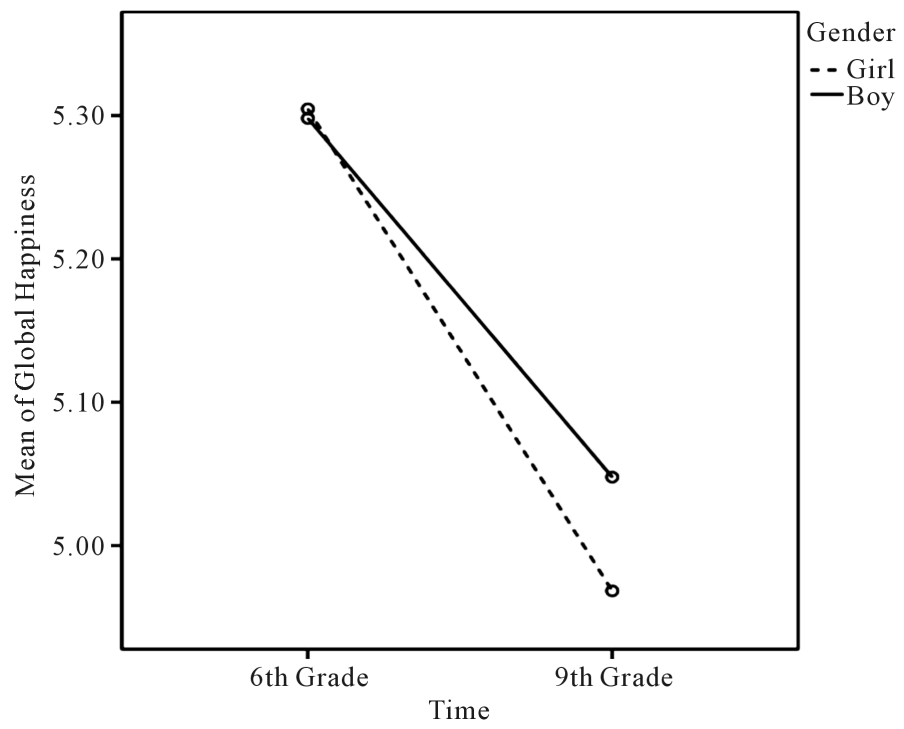

Figure 1. Change in global happiness from $6^{\text {th }}$ to $9^{\text {th }}$ grade in girls and Boys. Note: Scale in global happiness 1-7. 
Especially in girls, the decline in school-related happiness was dramatic. In the sixth grade, the mean of girls' and boys' school-related happiness was $3.28(S D=0.46)$ and $3.31(S D=0.32)$. Analysis of variance showed a significant main effect of time, $F(1)=40.71, p<0.001, \eta 2=0.04$ and gender, $F(1)=5.47, p<0.05, \eta 2=0.01$. There was no interaction effect between time and gender, $p>0.05$ (see Figure 2).

\subsection{What Would Make Students Happier?}

The percentages of items that make people happy chosen by the participants are shown in Table 2. Success in school was the most frequent choice, with ending alcohol usage the least frequent choice. The chi-square test revealed gender differences in three of the options. Girls more often than boys wanted clear plans for the future, $\chi^{2}(1)=9.66, p<0.001$; better looks, $\chi^{2}(1)=13.20, p<0.001$; and equality for all people, $\chi^{2}(1)=35.33, p<$ 0.001 . Overall, the distributions of all the desires differed between the genders, $\chi^{2}(18)=32.09, p<0.05$. The list of items that make people happy also included an open option that received 44 miscellaneous answers.

In addition to the happiness scales, we asked the students for their opinion on the change in global happiness using one three-part question: "Since the sixth grade, has your global happiness remained the same, decreased, or increased?” The respondents were also asked to describe qualitatively the reasons for the stability or change in their happiness. Of the girls and boys, $31.9 \%$ and $55.4 \%$, respectively, rated their happiness as unchanged during the past three years: among girls, $31.3 \%$ and, among boys, $19.1 \%$ believed their happiness had decreased; $36.8 \%$ of the girls and $25.5 \%$ of the boys believed their happiness had increased during the past three years.

A qualitative description for the change in happiness was given by $36.3 \%(n=123)$ of all participants. Thirtyseven respondents attributed increased happiness to having more friends, improved quality of friendships, or being romantically involved with someone. Greater self-confidence was mentioned by ten respondents. Decreased happiness was attributed to bullying, lack of friends, and other peer problems by 16 respondents. Stress in school was mentioned by ten respondents. In only five answers was family indicated as the cause of stability or change in happiness. The remaining descriptions fell into the category of miscellaneous.

Happiness-increasing factors had largely remained the same during the three years of high school. Among the sixth graders, better success in school, more free time, success in a hobby and a girlfriend or a boyfriend were the most desired choices (Uusitalo-Malmivaara, 2012). Among ninth graders, money had gained in importance, while success in a hobby no longer mattered as much.

\subsection{Groups According to the Scores on the Subjective Happiness Scale}

In order to assess specifically how participants with different levels of global happiness scored on individual items of the school happiness inventory and what happiness factors they selected, the data were divided into

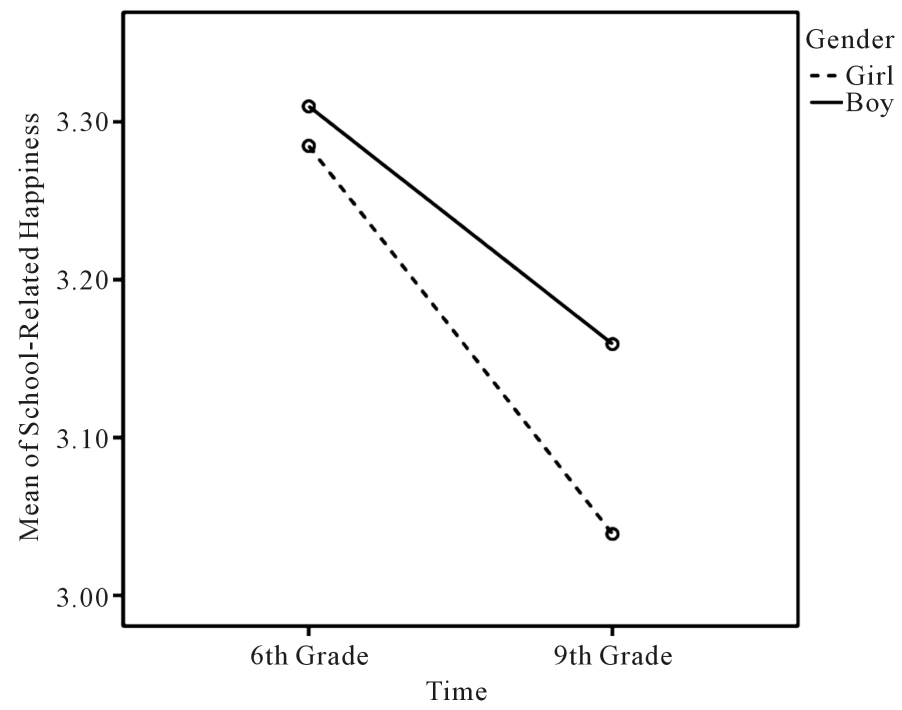

Figure 2. Change in school-related happiness from $6^{\text {th }}$ to $9^{\text {th }}$ grade in girls and boys. Note: Scale in school-related happiness 1-4. 
Table 2. What would increase my happiness? Percentages of choices in descending order.

\begin{tabular}{cccc}
\hline & Girls $(n=182) \%$ & Boys $(n=157) \%$ & Total \% $(n=339)$ \\
\hline Better success in school & 59.9 & 61.1 & 60.5 \\
More money & 61.0 & 58.6 & 59.9 \\
More free time & 53.8 & 58.0 & 55.8 \\
A girlfriend/boyfriend & 51.6 & 47.8 & 49.9 \\
Clear plans for the future** & 57.7 & 40.8 & 43.7 \\
Better looks ${ }^{* * *}$ & 33.1 & 41.0 \\
More friends & 52.7 & 36.3 & 35.4 \\
Better success at a hobby & 45.1 & 33.8 & 30.7 \\
People everywhere would be equal & 14.6 & 27.4 \\
Peaceful family life & 36.8 & 29.3 & 27.4 \\
A new hobby & 44.5 & 24.8 & 21.8 \\
I would dare to be myself & 25.8 & 18.5 & 21.5 \\
Climate change would end & 29.7 & 17.8 & 18.9 \\
Better health & 24.7 & 17.8 & 17.1 \\
Becoming a celebrity & 24.7 & 21.0 & 16.8 \\
Amproved spiritual life & 19.8 & 13.4 & 9.4 \\
\hline I would stop using alcohol and/or other drugs & 13.7 & 14.6 & 16.5 \\
\hline
\end{tabular}

Note: ${ }^{* * *}$ Difference between girls and boys, $p<0.001$.

rough quartiles, from Q1 (the least happy quartile) to Q4 (the happiest quartile), similar to our study of the sixth graders (Uusitalo-Malmivaara, 2012), see Table 3.

A one-way ANOVA revealed that the happiness quartiles differed in all but one item in the school-related happiness inventory (see Table 4). Especially, items examining positive affect (I felt relaxed, I felt positive, I felt good, I was confident, and I liked being with other people) were rated differently by the participants in different global happiness levels.

The Kruskal-Wallis test revealed that the happiness quartiles differed in four items on the list of happiness-increasing factors: better looks $\left(\chi^{2}(3)=12.92, p<0.01\right)$; daring to be oneself $\left(\chi^{2}(3)=11.30, p<0.05\right)$; improved spiritual life $\left(\chi^{2}(3)=11.85, p<0.01\right)$; and ending the use of alcohol, $\left(\chi^{2}(3)=8.91, p<0.05\right)$. Paired comparisons conducted with the Mann-Whitney U-test $(p s<0.001-0.05)$ showed that the desires expressed by Q1 and Q4 differed the most (see Table 5). More often than Q4, Q1 wanted to have better looks, a girlfriend or boyfriend, dare to be themselves, have a better spiritual life, have clear future plans, have their close friends or family stop using alcohol and stop using alcohol themselves. Q1 more often than Q3 wanted to dare to be themselves. Q2 more often than Q1 wanted to have more free time. Q2 more often than Q4 wanted to have more money, better looks, dare to be themselves, clear future plans, have close friends or family stop using alcohol, and stop using alcohol themselves. Q2 more often than Q3 wanted to have more free time and dare to be themselves. Q3 more often than Q4 wanted to have better looks, a better spiritual life, and stop using alcohol. Furthermore, Q1 and Q2 had a significantly higher number of expressed desires than Q4, $U=2193, p<0.01$, and $U$ $=2342, p<0.05$, respectively. The number of expressed desires consistently diminished as subjective happiness grew. In the happiest quartile, Q4, there were no special characteristics in the distribution of items that can make people happy.

Boys and girls possessed some unique features in the happiness quartiles. In Q1 (the least happy quartile), the girls more often than the boys wanted equality for all people $\left(\chi^{2}(1)=7.44, p<0.01\right)$ and clear future plans 
Table 3. Happiness quartiles.

\begin{tabular}{ccccccc}
\hline \multirow{2}{*}{ Happiness quartile } & $\begin{array}{c}\text { Scores on the subjective happiness } \\
\text { scale (global happiness) }\end{array}$ & Girls & Boys & Girls & Brequency \% \\
\cline { 3 - 7 } Q1 & $<-4.5$ & 56 & 47 & 30.8 & 29.9 \\
Q2 & $4.75-5.25$ & 57 & 45 & 31.3 & 28.7 & 22.3 \\
Q3 & $5.5-5.75$ & 39 & 35 & 21.4 & 16.5 & 19.1 \\
Q4 & $6.0-7.0$ & 30 & 30 & & 16.5 \\
\hline
\end{tabular}

Table 4. Univariate ANOVA and post hoc statistics for the SCHI scores by happiness quartiles. ${ }^{* *} p<0.01,{ }^{* * *} p<0.001$.

\begin{tabular}{|c|c|c|c|c|c|c|}
\hline & Q1 & Q2 & Q3 & Q4 & \multirow{2}{*}{$F(3335)$} & \multirow{2}{*}{$\eta 2$} \\
\hline & $M(S D)$ & $M(S D)$ & $M(S D)$ & $M(S D)$ & & \\
\hline I was nervous ${ }^{\mathrm{a}, \mathrm{e}}$ & $2.55(1.06)$ & $2.74(0.97)$ & $2.42(1.11)$ & $3.12(0.96)$ & $5.83^{* *}$ & 0.05 \\
\hline I wanted to come to school ${ }^{\mathrm{b}}$ & $2.50(1.10)$ & $2.92(0.93)$ & $3.00(1.05)$ & $3.28(0.96)$ & $8.24^{* * *}$ & 0.07 \\
\hline I was sad ${ }^{\mathrm{a}, \mathrm{c}, \mathrm{e}}$ & $2.88(1.20)$ & $3.59(0.88)$ & $3.31(1.06)$ & $3.850(.58)$ & $14.79^{* * *}$ & 0.12 \\
\hline I felt relaxed $\mathrm{d}^{\mathrm{a}, \mathrm{d}, \mathrm{e}}$ & $2.82(0.91)$ & $2.83(0.83)$ & $3.32(0.78)$ & $3.72(0.49)$ & $22.17^{* * *}$ & 0.17 \\
\hline I felt ill ${ }^{\mathrm{b}, \mathrm{e}, \mathrm{g}}$ & $2.82(1.13)$ & $3.45(0.89)$ & $3.27(1.06)$ & $3.90(0.40)$ & $17.88^{* * *}$ & 0.14 \\
\hline I felt that school was a safe place ${ }^{\mathrm{a}, \mathrm{d}, \mathrm{g}}$ & $2.80(1.10)$ & $3.01(0.97)$ & $3.36(0.85)$ & $3.45(0.72)$ & $8.47^{* * *}$ & 0.07 \\
\hline I concentrated $^{\mathrm{b}}$ & $2.49(1.04)$ & $2.93(0.82)$ & $3.12(0.83)$ & $3.30(1.03)$ & $12.71^{* * *}$ & 0.10 \\
\hline I felt sick & $2.86(1.06)$ & $2.98(1.00)$ & $2.95(1.08)$ & $3.32(1.03)$ & 2.52 & 0.02 \\
\hline I felt positive $\mathrm{e}^{\mathrm{a}, \mathrm{d}, \mathrm{e} g}$ & $2.53(0.91)$ & $2.84(0.77)$ & $3.14(0.80)$ & $3.50(0.73)$ & $20.00^{* * *}$ & 0.15 \\
\hline I felt angry ${ }^{\mathrm{a}, \mathrm{e}, \mathrm{g}}$ & $2.67(1.18)$ & $2.91(0.99)$ & 2.69 (1.19) & $3.53(0.83)$ & $9.55^{* * *}$ & 0.08 \\
\hline I wanted to cry ${ }^{\mathrm{a}, \mathrm{c}, \mathrm{g}}$ & $3.06(1.20)$ & $3.51(0.87)$ & $3.34(1.05)$ & $3.87(0.54)$ & $9.33^{* * * *}$ & 0.08 \\
\hline I got on well with everyone $e^{\mathrm{b}, \mathrm{e}, \mathrm{g}}$ & $2.83(0.96)$ & $3.25(0.78)$ & $3.32(0.81)$ & $3.67(0.68)$ & $13.94^{* * *}$ & 0.11 \\
\hline I was in a bad mood ${ }^{\mathrm{a}, \mathrm{e}, \mathrm{g}}$ & $2.60(0.99)$ & $2.91(0.98)$ & $2.81(1.08)$ & $3.53(0.72)$ & $12.06^{* * *}$ & 0.10 \\
\hline I enjoyed myself ${ }^{\mathrm{b}, \mathrm{g}}$ & $2.67(0.89)$ & $3.10(0.70)$ & $3.39(0.81)$ & $3.53(0.75)$ & $19.43^{* * *}$ & 0.15 \\
\hline I felt calm ${ }^{\text {a g g }}$ & $2.87(0.89)$ & $3.01(0.86)$ & $3.00(1.03)$ & $3.47(0.70)$ & $5.92^{* *}$ & 0.05 \\
\hline I was interested in working a d & $2.30(0.95)$ & $2.64(0.89)$ & $2.76(0.90)$ & $2.95(0.85)$ & $7.52^{* * * *}$ & 0.06 \\
\hline I felt sorry for myself ag & $3.15(1.00)$ & $3.45(0.86)$ & $3.49(0.94)$ & $3.77(0.56)$ & $6.58^{* * *}$ & 0.06 \\
\hline I felt good ${ }^{\mathrm{b}, \mathrm{f}}$ & $2.58(0.89)$ & $3.04(0.72)$ & $3.35(0.77)$ & $3.53(0.77)$ & $22.92^{* * *}$ & 0.17 \\
\hline I was confused $^{\mathrm{a}}$ & $2.72(1.09)$ & $2.94(1.03)$ & $3.00(1.07)$ & $3.38(0.85)$ & $5.32^{* *}$ & 0.05 \\
\hline I was confident ${ }^{\mathrm{a}, \mathrm{d}, \mathrm{f}}$ & $2.68(0.91)$ & $2.97(0.84)$ & $3.42(0.66)$ & $3.65(0.61)$ & $24.36^{* * *}$ & 0.18 \\
\hline I felt upset ${ }^{\mathrm{b}, \mathrm{e}, \mathrm{g}}$ & $2.99(1.06)$ & $3.44(0.95)$ & $3.410 .99)$ & $3.88(0.37)$ & $12.20^{* * *}$ & 0.10 \\
\hline I wanted to give $\mathrm{up}^{\mathrm{b}, \mathrm{g}}$ & $2.66(1.12)$ & $3.23(1.00)$ & $3.35(1.04)$ & $3.63(0.80)$ & $13.66^{* * *}$ & 0.11 \\
\hline I worked well $^{\mathrm{b}}$ & $2.60(0.84)$ & $2.92(0.79)$ & $3.22(0.71)$ & $3.25(0.80)$ & $12.35^{* * *}$ & 0.10 \\
\hline I was frightened ${ }^{\mathrm{a}, \mathrm{e}, \mathrm{g}}$ & $3.27(1.00)$ & $3.51(0.92)$ & $3.43(1.01)$ & $3.93(0.31)$ & $7.08^{* * * *}$ & 0.06 \\
\hline I liked being with other people $e^{\mathrm{b}, \mathrm{g}}$ & $2.92(1.08)$ & $3.50(0.77)$ & $3.72(0.56)$ & $3.83(0.59)$ & $21.54^{* * *}$ & 0.16 \\
\hline
\end{tabular}

Note: ${ }^{\mathrm{a}} \mathrm{Q} 1$ significantly lower than Q4, $p<0.001$ - 0.05; ${ }^{\mathrm{b}} \mathrm{Q} 1$ significantly lower than Q2, Q3, and Q4, $p<0.001$ - 0.05 ; ${ }^{\mathrm{c}} \mathrm{Q} 1$ significantly lower than $\mathrm{Q} 2, p<0.001-0.05$; ${ }^{\mathrm{d}} \mathrm{Q} 1$ significantly lower than $\mathrm{Q} 3, p<0.001-0.05$; ${ }^{\mathrm{Q}} \mathrm{Q} 3$ significantly lower than $\mathrm{Q} 4, p<0.001-0.05$; ${ }^{\mathrm{f}} \mathrm{Q} 2$ significantly lower than $\mathrm{Q} 3$ and Q4, $p<0.001-0.05$; ${ }^{\mathrm{g}} \mathrm{Q} 2$ significantly lower than Q4, $p<0.001-0.05$; Post hoc Scheffé in items 1, 8, 15, 16, 19, and 23; Dunnett's T3 in all other items. 
$\left(\chi^{2}(1)=10.39, p<0.01\right)$. In Q2, the girls more often than the boys wanted to have more friends, $\left(\chi^{2}(1)=6.60, p\right.$ $<0.05)$, better looks $\left(\chi^{2}(1)=16.05, p<0.001\right)$ and equality for all people, $\left(\chi^{2}(1)=7.37, p<0.01\right)$. In Q3, the boys more often than the girls wanted to have a peaceful family life $\left(\chi^{2}(1)=4.35, p<0.05\right)$. In Q3, the girls more often than the boys wanted equality for all people $\left(\chi^{2}(1)=12.50, p<0.001\right)$ and clear plans for future $\left(\chi^{2}(1)\right.$ $=4.33, p<0.05)$. In Q4, the boys more often than the girls wanted to have better success in school $\left(\chi^{2}(1)=5.46\right.$, $p<0.05)$, whereas the girls more often than the boys wanted climate change to end $\left(\chi^{2}(1)=4.73, p<0.05\right)$ and equality for all people $\left(\chi^{2}(1)=9.16, p<0.01\right)$.

\subsection{Grade-Point Average and Happiness}

The self-reported grade-point averages were distributed almost normally (data not shown). There was a statistically significant difference between the genders, with the girls' GPA distributions greater than those of the boys $\left(\chi^{2}(10)=25.55, p<0.01\right)$. Among the girls and boys, 30.2\% $(n=55)$ and 19.7\% $(n=31)$, respectively, had a GPA higher or equivalent to 8.6, a cut-point frequently used to define the highest achievers in Finland (GPA range 4 -10). We compared global and school-related happiness in students who scored lower than equal to or above this cut-off point (see Table 6). The girls in the high GPA group were happier than other girls both globally and in the school. Among the boys, there was no difference between the high achievers and the others. On the contrary, those in the low GPA group tended to be happier than those in the high GPA group, both globally and at school, although these differences were without statistical significance.

The girls in the two GPA groups differed on four items in their views of what would make them happier. Success in school $\left(\chi^{2}(1)=47.56, p<0.001\right)$, better health $\left(\chi^{2}(1)=5.68, p<0.05\right)$, a better spiritual life $\left(\chi^{2}(1)=\right.$ $4.34, p<0.05)$, and ending the use of alcohol $\left(\chi^{2}(1)=6.27, p<0.05\right)$ were wanted more by the lower GPA group. The boys in the lower GPA group wanted to have better success in school $\left(\chi^{2}(1)=24.18, p<0.001\right)$, more free time $\left(\chi^{2}(1)=5.88, p<0.05\right)$, more money $\left(\chi^{2}(1)=4.42, p<0.05\right)$, and clear future plans $\left(\chi^{2}(1)=6.74\right.$, $p<0.01$ ) more than did the boys in the higher GPA group.

\subsection{Future Plans and Happiness}

Of all the respondents, $55.8 \%$ (65.4\% of the girls and $44.6 \%$ of the boys) planned to continue in upper (academic) secondary school after finishing ninth grade. Vocational school was the choice of $35.7 \%$ ( $26.4 \%$ of the girls

Table 5. The Mann-Whitney U-test statistics for the happiness increasing factors by happiness quartiles.

\begin{tabular}{|c|c|c|c|c|c|c|c|c|c|c|}
\hline & $\begin{array}{l}\text { More } \\
\text { money }\end{array}$ & $\begin{array}{c}\text { More Free } \\
\text { Time }\end{array}$ & $\begin{array}{l}\text { Better } \\
\text { looks }\end{array}$ & $\begin{array}{l}\text { A Girl-/Boy } \\
\text { friend }\end{array}$ & $\begin{array}{l}\text { Dare to be } \\
\text { themselves }\end{array}$ & $\begin{array}{l}\text { Better } \\
\text { spiritual } \\
\text { life }\end{array}$ & $\begin{array}{l}\text { Clear future } \\
\text { plans }\end{array}$ & $\begin{array}{l}\text { Their close } \\
\text { friends/family would } \\
\text { stop using alcohol }\end{array}$ & $\begin{array}{l}\text { They would stop } \\
\text { using alcohol } \\
\text { themselves }\end{array}$ & \\
\hline Q1 & & & $2213^{* * *}$ & $2496^{*}$ & $2429^{* * *}$ & $2516^{* *}$ & $2582^{*}$ & $2696^{*}$ & $2700^{* *}$ & Q4 \\
\hline Q1 & & & & & $3305^{*}$ & & & & & Q3 \\
\hline Q2 & & $4404^{*}$ & & & & & & & & Q1 \\
\hline Q2 & & $3131^{*}$ & & & $3299^{*}$ & & & & & Q3 \\
\hline Q2 & $2490^{*}$ & & $2535^{*}$ & & $2526^{* *}$ & & $2391^{* *}$ & $2664^{*}$ & $2670^{* *}$ & Q4 \\
\hline Q3 & & & $1725^{*}$ & & & $1948^{*}$ & & & $2040^{*}$ & Q4 \\
\hline
\end{tabular}

Note: ${ }^{*} p<0.05,{ }^{* *} p<0.01,{ }^{* * *} p<0.001$. In each row, the quartile on the left side had more of the particular wish(es) than the quartile on the right.

Table 6. Descriptive statistics for global and school-related happiness measures and gender differences in two GPA groups.

\begin{tabular}{|c|c|c|c|c|c|c|c|c|c|c|c|c|c|c|c|c|}
\hline & \multicolumn{3}{|c|}{ Girls, GPA $<8.6$} & \multicolumn{3}{|c|}{ Girls, GPA $\geq 8.6$} & \multicolumn{2}{|c|}{ Difference } & \multicolumn{3}{|c|}{ Boys, GPA < 8.6} & \multicolumn{3}{|c|}{ Boys, GPA $\geq 8.6$} & \multicolumn{2}{|c|}{ Difference } \\
\hline & $n$ & $M$ & $S D$ & $n$ & $M$ & $S D$ & $t$ & $p$ & $n$ & $M$ & $S D$ & $n$ & $M$ & $S$ & $t$ & $p$ \\
\hline Global happiness & 127 & 4.80 & 1.04 & 55 & 5.36 & 0.95 & -3.42 & $<0.001$ & 26 & 5.09 & 0.98 & 31 & 4.87 & 0.96 & 1.13 & n.s. \\
\hline SCHI & 127 & 2.93 & 0.53 & 55 & 3.29 & 0.49 & -4.25 & $<0.05$ & 26 & 3.18 & 0.50 & 31 & 3.07 & 0.55 & 1.06 & n.s. \\
\hline
\end{tabular}

Note: Global happiness, scale 1-7; SCHI = School Children’s Happiness Inventory, scale 1-4. 
and $46.5 \%$ of the boys). Of all respondents, $7.4 \%$ were about to start work, take a year off, or had not yet decided what to do. Those who had chosen the academic track were significantly happier than those who had chosen vocational school, both globally, $M($ academic $)=5.16, S D=0.91, n=189, M($ vocational $)=4.88, S D=1.06$, $n=121, t(308)=3.44, p<0.05$, and in the school context, $M$ (academic) $=3.20, S D=0.49, M($ vocational $)=$ 3.02, $S D=0.55, t(308)=7.87, p<0.01$. The $7.4 \%$ of students with diverse future plans were not included in the comparisons because of the small sample sizes.

\section{Discussion}

Overall, the ninth graders in the present study seemed happy. Their average global happiness was of the same high magnitude obtained in previous studies (Lyubomirsky \& Lepper, 1999). Happiness in the school context was lower than previously documented by Ivens (2007), but about the same as in our previous studies on Finnish students (Uusitalo-Malmivaara, 2012; Uusitalo-Malmivaara et al., 2012). Reduced satisfaction and low wellbeing in academically high-achieving Finnish students (e.g., Hautamäki et al., 2008) has become a kind of mantra in numerous reports (Linnakylä, 1996; Malin \& Linnakylä, 2001; Terveyden ja hyvinvoinnin laitos, 2012). In a recent comparison of 36 countries, Finnish 15-year-olds were in twenty-seventh place in liking school somewhat or a lot (Kämppi et al., 2012: p. 30). However, it appears that liking school had increased in the past ten years (Kämppi et al., 2012: p. 21). At the same time, the burden of schoolwork had increased. Finland was in fourth place (boys) and in third place (girls) in the same international comparison when school-related burnout was examined (Kämppi et al., 2012: p. 43; see also Salmela-Aro et al., 2008).

The school-related happiness inventory used in the present study measured both positive and negative effects in social and academic contexts during the previous school week. In accordance with studies on depression and school-related burn-out (Nolen-Hoeksema, 1994; Salmela-Aro et al., 2008), girls scored lower than boys on this inventory. Our results document a rather deep decline in girls' school-related well-being during the ages from 12 to 15. Boys' school-related happiness had also decreased, but not as sharply. The reasons for girls' lower school happiness may lie in the multifaceted and controversial demands placed on them. While girls are expected to do well in school, in Finland they are brought up to be fiercely independent, but they may still have less freedom than boys (see also Nolen-Hoeksema, 1994). Adolescent girls also have greater pressure than boys because of their looks, weight being of a special concern. According to the recent, large-scale School Health Promotion Study (Finland's National Institute for Health and Welfare, 2012), 36\% of girls in the eighth and ninth grades considered themselves slightly or clearly overweight. Among the boys, the corresponding percentage was 19\%.

In our previous study, better success in school was the most desired happiness-increasing factor among sixth graders (Uusitalo-Malmivaara, 2012). In the current study, the importance of academic success had grown. About $60 \%$ of all respondents thought that their happiness would increase with improved grades. As much as ten percent of those with already a high GPA $(\geq 8.6)$ agreed on that. Among all respondents, a high GPA was moderately associated with elevated global and school-related happiness. However, there was a significant difference between the genders. Girls in the high GPA group were happier than other girls, but for boys, being academically among the highest achievers did not seem to have an effect on either global or school-related happiness. Thus, academic success is of greater importance for girls than for boys, a result found in previous studies, as well (Murberg \& Bru, 2004; Salmela-Aro et al., 2008; Salmela-Aro \& Tuominen-Soini, 2010).

More money and more free-time were the second- and third-most factors for increasing happiness. Only about $34 \%$ of the sixth graders believed that money would add to their happiness but, three years later, almost $60 \%$ wanted more of money. Since adolescence is a time of materialism and consumerism is part of western teenage culture, this comes as no surprise. Money produces short-term spurts in positive affect (Diener \& Biswas-Diener, 2002). Also, as students without constant income, many respondents actually have very little money to spend on anything. In some Finnish families, youths' pocket money is dependent on good grades, which are rewarded with extra cash. This kind of extrinsic motivation may further emphasize the need to do better in school.

Having clear future plans was a wish made by almost half of all respondents. The transition from lower secondary school to either upper secondary (academic) school or to vocational education (or directly into the labor market) is the most decisive educational watershed in the Finnish school system. Every year, about six percent of those ending compulsory school are left without a place of study at the upper secondary level (Finnish Ministry of Employment and the Economy, 2012); certainly, this transition is a cause of stress for many. In the current study, those who knew they would probably enter upper secondary school (i.e., pursuit academic track) were 
happier than those on their way to a vocational school. This is in line with previous studies showing increased life satisfaction in those about to continue general, academic education compared to those entering a vocational school (Salmela-Aro \& Tuominen-Soini, 2010). Those heading to upper secondary school usually have higher GPAs and more freedom to choose than those on their way to vocational school. Also, those who choose the academic track still have some years ahead to make exact career plans. However, regardless of the track chosen, life satisfaction seems to increase in both genders after the transition to upper secondary education in both genders (Salmela-Aro \& Tuominen-Soini, 2010).

Those who described reasons for change in happiness during lower secondary school years mostly addressed social issues. However, family life was commented on by only five, rather extreme accounts (such as the death of a family member). This suggests that 15 -year-olds prioritize their peer relations as a source of happiness, and, most likely, they have homes good enough not to need mentioning. The overwhelming importance of friends is further shown by the peer problems evident among the globally unhappiest respondents. More seldom than others did they feel relaxed or confident at school, nor did they like being with other people. They thought their happiness would increase if they looked better and dared to be themselves. Also, an improved spiritual life and stopping the use of alcohol were desires of the unhappiest students.

\subsection{Limitations of the Study}

Several limitations should be noted. First, the participants in this study were drawn from one city, and the results may not be generalized to other locations. Second, only about $40 \%$ of the respondents in the first wave of the study (the sixth graders) were included in the second wave, and about $14 \%$ of the participants in the second wave (the ninth graders) were not included in the first wave. Third, the list of the putative happiness-increasing factors included only 19 items and one open option. The options given may have directed the answers. Fourth, measuring happiness in the spring term of the ninth grade may give an over-pessimistic picture of the students' happiness, since this is a time of extra stress, owing to the forthcoming transition to upper secondary school education.

\subsection{Conclusion}

For many ninth graders, school seemed like hard work. Academic success was highly valued, and the importance of good grades was certainly acknowledged, especially by the girls. The approaching transition to upper secondary school education worried many. However, decreased happiness was attributed to school failure only by a small minority. Instead, peer relationships played a crucial role in determining the change in happiness during the three years in the lower secondary school. Among the globally unhappiest, both peer and academic issues were problematic.

Future research is needed to determine whether school-related happiness could be maintained through the years of early adolescence. Since happiness not only is a desirable outcome in itself but also a strong predictor of future quality of life, promoting happiness in youth is crucial. Furthermore, the reasons why high subjective well-being precedes future success requires more research (Diener, 2012). Baker and Maupin stated that "the development of children's well-being should be a central focus of schooling” (Baker \& Maupin, 2009: p. 195). Paradoxically, at the end of compulsory school, students' well-being seems to be at its lowest. The current study adds one more piece of growing evidence to document the decline in subjective well-being during the early adolescence. Our results along with numerous previous studies call for explicit actions focused on promoting well-being through secondary school. This includes paying attention to the positive aspects of the youths' development and identifying and building on their strengths. Teaching of core correlates of well-being, such as optimism, hope, kindness, and gratitude, should be rooted at the curricular level (for interventions, see Emmons \& McCullough, 2003; Lyubomirsky, Dickerhoof, Boehm, \& Sheldon, 2011; Otake, Shimai, Tanaka-Matsumi, Otsui, \& Fredrickson, 2006; Seligman, Steen, Park, \& Peterson, 2005). And finally, because social relationships are necessary components of happiness (Diener \& Oishi, 2005), sociability should be actively fostered. This means that developing and maintaining positive relationships needs to be taught continuously and not simply as part of anti-bullying programs.

\section{References}

Angold, A., Costello, E. J., Erkali, A., \& Worthman, C. M. (1999). Pubertal changes in Hormone Levels and Depression in 
Girls. Psychological Medicine, 29, 1043-1053. http://dx.doi.org/10.1017/S0033291799008946

Baird, B. M., Lucas, R. E., \& Donnellan, M. B. (2010). Life Satisfaction across the Lifespan: Findings from Two Nationally Representative Panel Studies. Social Indicators Research, 99, 183-203. http://dx.doi.org/10.1007/s11205-010-9584-9

Baker, J. A., Dilly, L. J., Aupperlee, J. L., \& Patil, S. A. (2003). The Developmental Context of School Satisfaction: Schools as Psychologically Healthy Environments. School Psychology Quarterly, 18, 206-221. http://dx.doi.org/10.1521/scpq.18.2.206.21861

Baker, J. A., \& Maupin, A. N. (2009). School Satisfaction and Children’s Positive School Adjustment. In R. Gilman, E. S. Huebner, \& M. J. Furlong (Eds.), Handbook of Positive Psychology in Schools (pp. 189-196). New York: Routledge.

Bisegger, C., Cloetta, B., von Bisegger, U., Abel, T., Ravens-Sieberer, U., \& European Kidscreen Group (2005). HealthRelated Quality of Life: Gender Differences in Childhood and Adolescence. Sozial- Und Präventivmedizin, 50, $281-291$. http://dx.doi.org/10.1007/s00038-005-4094-2

Brantley, A., Huebner, E. S., \& Nagle, R. J. (2002). Multidimensional Life Satisfaction Reports of Adolescents with Mild Mental Disabilities. Mental Retardation, 40, 321-329.

http://dx.doi.org/10.1352/0047-6765(2002)040<0321:MLSROA>2.0.CO;2

Brooks-Gunn, J., \& Petersen, A. C. (1991). Studying the Emergence of Depression and Depressive Symptoms during Adolescence. Journal of Youth and Adolescence, 20, 115-119. http://dx.doi.org/10.1007/BF01537603

Chang, L., McBride-Chang, C., Stewart, S. M., \& Au, E. (2003). Life Satisfaction, Self-Concept, and Family Relations in Chinese Adolescents and Children. International Journal of Behavioral Development, 27, 182. http://dx.doi.org/10.1080/01650250244000182

Chaplin, L. (2009). Please May I Have a Bike? Better yet, May I Have a Hug? An Examination of Children’s and Adolescents’ Happiness. Journal of Happiness Studies, 10, 541-562. http://dx.doi.org/10.1007/s10902-008-9108-3

Cheng, H., \& Furnham, A. (2003). Personality, Self-Esteem, and Demographic Predictions of Happiness and Depression. Personality \& Individual Differences, 34, 921-942. http://dx.doi.org/10.1016/S0191-8869(02)00078-8

Csikszentmihalyi, M., \& Hunter, J. (2003). Happiness in Everyday Life: The Uses of Experience Sampling. Journal of Happiness Studies, 4, 185-199. http://dx.doi.org/10.1023/A:1024409732742

Deci, E. L., \& Ryan, R. M. (1985). Intrinsic Motivation and Self-Determination in Human Behavior. New York: Plenum. http://dx.doi.org/10.1007/978-1-4899-2271-7

Demir, M., \& Özdemir, M. (2010). Friendship, Need Satisfaction and Happiness. Journal of Happiness Studies, 11, $243-259$. http://dx.doi.org/10.1007/s10902-009-9138-5

Demir, M., Şimşek, D. Ö., \& Procsal, A. D. (2012). I Am So Happy 'Cause My Best Friend Makes Me Feel Unique: Friendship, Personal Sense of Uniqueness and Happiness. Journal of Happiness Studies, 14, 1201-1224.

http://dx.doi.org/10.1007/s10902-012-9376-9

Demir, M., \& Weitekamp, L. A. (2007). I Am So Happy 'Cause Today I Found My Friend: Friendship and Personality as Predictors of Happiness. Journal of Happiness Studies, 8, 181-211. http://dx.doi.org/10.1007/s10902-006-9012-7

Diener, E. (1984). Subjective Well-Being. Psychological Bulletin, 95, 542-575. http://dx.doi.org/10.1037/0033-2909.95.3.542

Diener, E. (1995). Resources, Personal Strivings, and Subjective Well-Being: A Nomothetic and Idiographic Approach. Journal of Personality and Social Psychology, 68, 926-935. http://dx.doi.org/10.1037/0022-3514.68.5.926

Diener, E. (1996). Traits Can Be Powerful, but Are Not Enough: Lessons from Subjective Well-Being. Journal of Research in Personality, 30, 389-399. http://dx.doi.org/10.1006/jrpe.1996.0027

Diener, E. (2012). New Findings and Future Directions for Subjective Well-Being Research. American Psychologist, 67, 590-597. http://dx.doi.org/10.1037/a0029541

Diener, E., Sandvik, E., Seidlitz, L., \& Diener, M. (1993). The Relationship between Income and Subjective Well-Being: Relative or Absolute? Social Indicators Research, 28, 195-223. http://dx.doi.org/10.1007/BF01079018

Diener, E., \& Biswas-Diener, R. (2002). Will Money Increase Subjective Well-Being? Social Indicators Research, 57, 119169. http://dx.doi.org/10.1023/A:1014411319119

Diener, E., \& Oishi, S. (2005). The Nonobvious Social Psychology of Happiness. Psychological Inquiry, 16, $162-167$. http://dx.doi.org/10.1207/s15327965pli1604_04

Dunn, E. W., Aknin, L. B., \& Norton, M. I. (2008). Spending Money on Others Promotes Happiness. Science, 319, 16871688. http://dx.doi.org/10.1126/science.1150952

Eagly, A. H., Ashmore, R. D., Makhijani, M. G., \& Longo, L. C. (1991). What Is Beautiful Is Good, but...: A Meta-Analytic Review of Research on the Physical Attractiveness Stereotype. Psychological Bulletin, 110, 109-128.

http://dx.doi.org/10.1037/0033-2909.110.1.109 
Emmons, R. A., \& McCullough, M. E. (2003). Counting Blessings versus Burdens: An Experimental Investigation of Gratitude and Subjective Well-Being in Daily Life. Journal of Personality \& Social Psychology, 84, 377-389.

http://dx.doi.org/10.1037/0022-3514.84.2.377

European Commission (2000). Report on the State of Young People's Health in the European Union: A Commission Services Working Paper. http://ec.europa.eu/health/ph_information/reporting/ke01_en.pdf

Feingold, A. (1992). Good-Looking People Are Not What We Think. Psychological Bulletin, 111, 304-341. http://dx.doi.org/10.1037/0033-2909.111.2.304

Finland's National Institute for Health and Welfare (2012). Kouluterveyskysely 2010-2011 [School Health Study 20112012]. http://info.stakes.fi/kouluterveyskysely/FI/tulokset/index.htm

Finnish Ministry of Employment and the Economy (2012). Nuorten yhteiskuntatakuu 2013.[Societal Guarantee for Youth]. Ministry of Employment and the Economy, Helsinki.

Finnish National Board (2012). Basic Education. http://www.oph.fi/english/education/basic_education.

Fredricks, J. A., Alfred-Liro, C. J., Hruda, L. Z., Eccles, J. S., Patrick, H., \& Ryan, A. M. (2002). A Qualitative Exploration of Adolescents' Commitment to Athletics and the Arts. Journal of Adolescent Research, 17, 68-97. http://dx.doi.org/10.1177/0743558402171004

Furnham, A., \& Cheng, H. (2000). Lay Theories of Happiness. Journal of Happiness Studies, 1, 227-246. http://dx.doi.org/10.1023/A:1010027611587

Gilman, R., \& Huebner, E. S. (1997). Children’s Reports of Their Life Satisfaction: Convergence across Raters, Time, and Response Formats. School Psychology International, 18, 229-243. http://dx.doi.org/10.1177/0143034397183004

Gilman, R., \& Huebner, E. S. (2003). A Review of Life Satisfaction Research with Children and Adolescents. School Psychology Quarterly, 8, 192-205. http://dx.doi.org/10.1521/scpq.18.2.192.21858

Gilman, R., \& Huebner, E. S. (2006). Characteristics of Adolescents Who Report Very High Life Satisfaction. Journal of Youth \& Adolescence, 35, 293-301. http://dx.doi.org/10.1007/s10964-006-9036-7

Goldbeck, L., Schmitz, T. G., Besier, T., Herschbach, P., \& Henrich, G. (2007). Life Satisfaction Decreases during Adolescence. Quality of Life Research, 16, 969-979. http://dx.doi.org/10.1007/s11136-007-9205-5

Hankin, B. L., Abramson, L. Y., Moffitt, T. E., Silva, P. A., McGee, R., \& Angell, K. E. (1998). Development of Depression from Preadolescence to Young Adulthood: Emerging Gender Differences in a 10-Year Longitudinal Study. Journal of Abnormal Psychology, 107, 128-140. http://dx.doi.org/10.1037/0021-843X.107.1.128

Hautamäki, J., Harjunen, E., Hautamäki, A., Karjalainen, T., Kupiainen, S., Laaksonen, S., Jakku-Sihvonen, R. et al. (2008). PISA 06 Finland. Analyses, Reflections and Explanations. Ministry of Education Publications.

Havighurst, R. J. (1966). Developmental Tasks and Education. New York: McKay.

Holder, M. D., Coleman, B., \& Sehn, Z. (2009). The Contribution of Active and Passive Leisure to Children's Well-Being. Journal of Health Psychology, 14, 378-386. http://dx.doi.org/10.1177/1359105308101676

Holder, M. D., Coleman, B., \& Singh, K. (2012). Temperament and Happiness in Children in India. Journal of Happiness Studies, 13, 261-274. http://dx.doi.org/10.1007/s10902-011-9262-x

Holder, M. D. (2012). Happiness in Children. Measurement, Correlates and Enhancement of Positive Subjective Well-Being. New York: Springer. http://dx.doi.org/10.1007/978-94-007-4414-1

Holder, M. D., \& Coleman, B. (2008). The Contribution of Temperament, Popularity, and Physical Appearance to Children’s Happiness. Journal of Happiness Studies, 9, 279-302. http://dx.doi.org/10.1007/s10902-007-9052-7

Holder, M. D., \& Coleman, B. (2009). The Contribution of Social Relationships to Children's Happiness. Journal of Happiness Studies, 10, 329-349. http://dx.doi.org/10.1007/s10902-007-9083-0

Holder, M. D., \& Klassen, A. (2010). Temperament and Happiness in Children. Journal of Happiness Studies, 11, 419-439. http://dx.doi.org/10.1007/s10902-009-9149-2

Huebner, E. S. (1991). Correlates of Life Satisfaction in Children. School Psychology Quarterly, 6, 103-111. http://dx.doi.org/10.1037/h0088805

Huebner, E. S., Gilman, R., \& Laughlin, J. E. (1999). A Multimethod Investigation of the Multidimensionality of Children's Well-Being Reports: Discriminant Validity of Life Satisfaction and Self-Esteem. Social Indicators Research, 46, 1-22. http://dx.doi.org/10.1023/A:1006821510832

Huebner, E. S., \& McCullough, G. (2000). Correlates of School Satisfaction among Adolescents. Journal of Educational Research, 93, 331-335. http://dx.doi.org/10.1080/00220670009598725

Ivens, J. (2007). The Development of a Happiness Measure for Schoolchildren. Educational Psychology in Practice, 23, 221-239. http://dx.doi.org/10.1080/02667360701507301

Kaltiala-Heino, R., Marttunen, M., Rantanen, P., \& Rimpelä, M. (2003). Early Puberty Is Associated with Mental Health 
Problems in Middle Adolescence. Social Science \& Medicine, 57, 1055-1064.

Kämppi, K., Välimaa, R., Ojala, K., Tynjälä, J., Haapasalo, I., Villberg, J., \& Kannas, L. (2012). Koulukokemusten kansainvälistä vertailua 2010 sekä muutokset suomessa ja pohjoismaissa 1994-2010. WHO-Koululaistutkimus (HBSC-Study). [International Comparison of School Experiences 2010 and Changes in FINLAND and Nordic Countries 1994-2010. HBSC Study by WHO.]. Koulutuksen seurantaraportit 2012:8, Opetushallitus.

Karvonen, S., Vikat, A., \& Rimpelä, M. (2005). The Role of School Context in the Increase in Young People’s Health Complaints in Finland. Journal of Adolescence, 28, 1-16. http://dx.doi.org/10.1016/j.adolescence.2004.05.006

Keyes, C. L. M. (2005). Mental Illness and/or Mental Health? Investigating Axioms of the Complete State Model of Health. Journal of Consulting and Clinical Psychology, 73, 539-548. http://dx.doi.org/10.1037/0022-006X.73.3.539

Linnakylä, P. (1996). Quality of School Life in the Finnish Comprehensive School: A Comparative View. Scandinavian Journal of Educational Research, 40, 69-85. http://dx.doi.org/10.1080/0031383960400105

Lyubomirsky, S., \& Lepper, H. S. (1999). A Measure of Subjective Happiness: Preliminary Reliability and Construct Validation. Social Indicators Research, 46, 137-155. http://dx.doi.org/10.1023/A:1006824100041

Lyubomirsky, S., Sheldon, K. M., \& Schkade, D. (2005). Pursuing Happiness: The Architecture of Sustainable Change. Review of General Psychology, 9, 111-131. http://dx.doi.org/10.1037/1089-2680.9.2.111

Lyubomirsky, S., Dickerhoof, R., Boehm, J. K., \& Sheldon, K. M. (2011). Becoming Happier Takes Both a Will and a Proper Way: An Experimental Longitudinal Intervention to Boost Well-Being. Emotion, 11, 391-402.

http://dx.doi.org/10.1037/a0022575

Malin, A., \& Linnakylä, P. (2001). Multilevel Modelling in Repeated Measures of the Quality of Finnish School Life. Scandinavian Journal of Educational Research, 45, 145-166. http://dx.doi.org/10.1080/00313830120052732

McCullough, G., \& Huebner, E. S. (2003). Life Satisfaction Reports of Adolescents with Learning Disabilities and Normally Achieving Adolescents. Journal of Psychoeducational Assessment, 21, 311-324. http://dx.doi.org/10.1177/073428290302100401

McKnight, C. G., Huebner, E. S., \& Suldo, S. (2002). Relationships among Stressful Life Events, Temperament, Problem Behavior, and Global Life Satisfaction in Adolescents. Psychology in the Schools, 39, 677-687. http://dx.doi.org/10.1002/pits.10062

Murberg, T. A., \& Bru, E. (2004). School-Related Stress and Psychosomatic Symptoms among Norwegian Adolescents. School Psychology International, 25, 317-332. http://dx.doi.org/10.1177/0143034304046904

Natvig, G. K., Albrektsen, G., \& Qvarnstrøm, U. (2003). Associations between Psychosocial Factors and Happiness among School Adolescents. International Journal of Nursing Practice, 9, 166-175.

http://dx.doi.org/10.1046/j.1440-172X.2003.00419.x

Neto, F. (2001). Personality Predictors of Happiness. Psychological Reports, 88, 817-824. http://dx.doi.org/10.2466/pr0.2001.88.3.817

Nickerson, C., Schwarz, N., Diener, E., \& Kahneman, D. (2003). Zeroing in on the Dark Side of the American Dream A Closer Look at the Negative Consequences of the Goal for Financial Success. Psychological Science, 14, 531-536. http://dx.doi.org/10.1046/j.0956-7976.2003.psci_1461.x

Nolen-Hoeksema, S., \& Girgus, J. S. (1994). The Emergence of Gender Differences in Depression during Adolescence. Psychological Bulletin, 115, 424-443. http://dx.doi.org/10.1037/0033-2909.115.3.424

Otake, K., Shimai, S., Tanaka-Matsumi, J., Otsui, K., \& Fredrickson, B. L. (2006). Happy People Become Happier through Kindness: A Counting Kindnesses Intervention. Journal of Happiness Studies, 7, 361-375. http://dx.doi.org/10.1007/s10902-005-3650-z

Park, N. (2005). Life Satisfaction among Korean Children and Youth. School Psychology International, 26, 209-223. http://dx.doi.org/10.1177/0143034305052914

Park, N., \& Huebner, E. S. (2005). A Cross-Cultural Study of the Levels and Correlates of Life Satisfaction among Adolescents. Journal of Cross-Cultural Psychology, 36, 444-456. http://dx.doi.org/10.1177/0022022105275961

Park, N., \& Peterson, C. (2006). Moral Competence and Character Strengths among Adolescents: The Development and Validation of the Values in Action Inventory of Strengths for Youth. Journal of Adolescence, 29, 891-909. http://dx.doi.org/10.1016/j.adolescence.2006.04.011

Park, N., \& Peterson, C. (2008). Positive Psychology and Character Strengths: Application to Strengths-Based School Counseling. Professional School Counseling, 12, 85-92. http://dx.doi.org/10.5330/PSC.n.2010-12.85

Petersen, A. C., Compas, B., Brooks-Gunn, J., Stemmler, M., Ey, S., \& Grant, K. E. (1993). Depression in Adolescence. The American Psychologist, 48, 155-168. http://dx.doi.org/10.1037/0003-066X.48.2.155

Peterson, C., Ruch, W., Beermann, U., Park, N., \& Seligman, M. E. P. (2007). Strengths of Character, Orientations to Happi- 
ness, and Life Satisfaction. Journal of Positive Psychology, 2, 149-156. http://dx.doi.org/10.1080/17439760701228938

Powers, S. I., Hauser, S. T., \& Kilner, L. A. (1989). Adolescent Mental Health. The American Psychologist, 44, $200-208$. http://dx.doi.org/10.1037/0003-066X.44.2.200

Proctor, C., Linley, P., \& Maltby, J. (2009). Youth Life Satisfaction: A Review of the Literature. Journal of Happiness Studies, 10, 583-630. http://dx.doi.org/10.1007/s10902-008-9110-9

Rask, K., Astedt-Kurki, P., Paavilainen, E., \& Laippala, P. (2003). Adolescent Subjective Well-Being and Family Dynamics. Scandinavian Journal of Caring Sciences, 17, 129-138.

Sacker, A., \& Cable, N. (2006). Do Adolescent Leisure-Time Physical Activities Foster Health and Well-Being in Adulthood? Evidence from Two British Birth Cohorts. European Journal of Public Health, 16, 331-335. http://dx.doi.org/10.1093/eurpub/cki189

Salmela-Aro, K., Kiuru, N., Pietikäinen, M., \& Jokela, J. (2008). Does School Matter? The Role of School Context in Adolescents’ School-Related Burnout. European Psychologist, 13, 12-23. http://dx.doi.org/10.1027/1016-9040.13.1.12

Salmela-Aro, K., \& Tuominen-Soini, H. (2010). Adolescents’ Life Satisfaction during the Transition to Post-Comprehensive Education: Antecedents and Consequences. Journal of Happiness Studies, 11, 683-701. http://dx.doi.org/10.1007/s10902-009-9156-3

Seligman, M. E. P., Steen, T. A., Park, N., \& Peterson, C. (2005). Positive Psychology Progress: Empirical Validation of Interventions. American Psychologist, 60, 410-421. http://dx.doi.org/10.1037/0003-066X.60.5.410

Suldo, S. M., Riley, K., \& Shaffer, E. S. (2006). Academic Correlates of Children and Adolescents' Life Satisfaction. School Psychology International, 27, 567-582. http://dx.doi.org/10.1177/0143034306073411

Suldo, S. M., \& Huebner, E. S. (2004). The Role of Life Satisfaction in the Relationship between Authoritative Parenting Dimensions and Adolescent Problem Behavior. Social Indicators Research, 66, 165-195. http://dx.doi.org/10.1023/B:SOCI.0000007498.62080.1e

Uusitalo-Malmivaara, L. (2012). Global and School-Related Happiness in Finnish School Children. Journal of Happiness Studies, 13, 601-619. http://dx.doi.org/10.1007/s10902-011-9282-6

Uusitalo-Malmivaara, L., \& Lehto, J. E. (2013). Social Factors Explaining Children’s Subjective Happiness and Depressive Symptoms. Social Indicators Research, 111, 603-615. http://dx.doi.org/10.1007/s11205-012-0022-z

Uusitalo-Malmivaara, L., Kankaanpää, P., Mäkinen, T., Raeluoto, T., Rauttu, K. Tarhala,V., \& Lehto, J. E. (2012). Are Special Education Children Happy? Scandinavian Journal of Educational Research, 56, 419-437. http://dx.doi.org/10.1080/00313831.2011.599421

Veenhoven, R., \& Ehrhardt, J. (1995). The Cross-National Pattern of Happiness: Test of Predictions Implied in Three Theories of Happiness. Social Indicators Research, 34, 33-68. http://dx.doi.org/10.1007/BF01078967 